\section{Day and night respiration of three tree species in a temperate forest of northeastern China}

\author{
Jinwei Sun ${ }^{(1-2)}$, Dexin Guan ${ }^{(1)}$, Jiabing Wu ${ }^{(1)}$, Yanli Jing ${ }^{(1-2)}$, Fenghui \\ Yuan ${ }^{(1-2)}$, Anzhi Wang ${ }^{(1)}$, Changjie Jin ${ }^{(1)}$
}

Leaf day respiration is one of the most fundamental plant physiological processes and plays a vital role in the plant carbon cycle. However, day respiration is inherently complex and difficult to measure. In this study, the Kok method and the Laisk method were used to measure leaf day respiration on saplings of one evergreen conifer species (Pinus koraiensis) and two deciduous broadleaved species (Tilia amurensis and Fraxinus mandshurica) in a temperate forest of northeastern China. Results show that discrepancy between the corrected day respiration values estimated by the Kok and Laisk methods was only $4 \%$ for the three tree species. On average, day respiration was $55.9 \%$ and $\mathbf{5 2 . 6 \%}$ lower compared to night respiration for the three tree species, as measured by the Kok and the Laisk method, respectively. Day respiration of the evergreen conifer species estimated by the Kok method was $31.7 \%$ lower, while that estimated by the Laisk method was $36.8 \%$ lower than that of the deciduous broadleaved species. Night respiration of the evergreen conifer trees was $\mathbf{4 0 . 7 \%}$ lower than those obtained for the deciduous broadleaved trees. Day respiration rate was positively correlated with night respiration rate. Notably, day respiration rate decreased with increased photosynthetic photon flux density, and even a small amount of light significantly inhibited leaf day respiration in all the three species.

Keywords: Dark Respiration, Deciduous Broadleaved Tree, Evergreen Conifer Tree, Gross Primary Production, Light Inhibition, Temperate Forest

\section{Introduction}

Dark respiration (non-photorespiratory respiration), which occurs both in light and in darkness, has a critical function in modulating the carbon balance of plants and terrestrial ecosystems. Ryan (1991) showed that the proportion of carbon consumption by respiration is nearly $70 \%$ of the total photo-

(1) State Key Laboratory of Forest and Soil Ecology, Institute of Applied Ecology, Chinese Academy of Sciences, Shenyang 110016 (China); (2) Graduate University of Chinese Academy of Sciences, Beijing 100049 (China)

\section{@ Jiabing Wu (wujb@iae.ac.cn)}

Received: Feb 28, 2013 - Accepted: Mar 31, 2014

Citation: Sun J, Guan D, Wu J, Jing Y, Yuan F, Wang A, Jin C, 2015. Day and night respiration of three tree species in a temperate forest of northeastern China. iForest 8: 25-32 [online 2014-05-26] URL: http://www.sisef.it/iforest/contents/? id=ifor0982-007

Communicated by: Giustino Tonon synthetic carbon fixation, and leaf respiration accounts for approximately $50 \%$ of total plant respiration (Poorter et al. 1991). At the ecosystem level, $\mathrm{CO}_{2}$ emission from plant respiration accounts for $30-70 \%$ of the total ecosystem $\mathrm{CO}_{2}$ exchange (Amthor 2000). Plant respiration releases $60 \mathrm{Gt} \mathrm{C} \mathrm{yr}^{-1}$ into the atmosphere (Schimel 1995). Therefore, understanding the carbon cycle of terrestrial ecosystems requires a more thorough understanding of the characteristics of leaf respiration.

Due to difficulty in directly measuring leaf day respiration $\left(R_{\mathrm{L}}\right)$, it is often assumed to be equal to night respiration (Poorter et al. 1990, 1992, Collier et al. 1992, Atkin et al. 1996). However, Kok (1948) found that net $\mathrm{CO}_{2}$ assimilation rate $\left(A_{\mathrm{n}}\right)$ rapidly decreased near the light compensation point, leading to the conclusion that leaf respiration may vary with light intensity. Indeed, McCashin et al. (1988) found that ${ }^{14} \mathrm{CO}_{2}$ production during tricarboxylic acid cycle is approximately $20 \%$ lower in light than in darkness, which indicates that day respiration is inhibited in light. Subsequent studies confirmed that day respiration rates are lower than night respiration rates. Using stable ${ }^{12} \mathrm{C} /{ }^{13} \mathrm{C}$ isotope techniques, Tcherkez et al. (2005) found that two main processes (glycolysis and the Krebs cycle) of day respiration are strongly inhibited in illuminated leaves of French bean. Thus, plant respiration in light is overestimated if $R_{\mathrm{L}}$ is assessed using data obtained during nighttime (Graham 1980, Sharp et al. 1984, Kirschbaum \& Farquhar 1987, Kromer 1995, Atkin et al. 1997, Hoefnagel et al. 1998, Ayub et al. 2011).

Plant respiration is a critical component of the gross primary production (GPP). Therefore, it is important to take into account the inhibitory effect of light on leaf respiration in order to obtain sound estimates of GPP. Wohlfahrt et al. (2005) estimated a reduction of $11-17 \%$ in GPP due to light inhibition in a mountain meadow, as compared to GPP model based on night respiration. Janssens et al. (2001) proposed that assessing day respiration by extrapolating night respiration results in an overestimation of $\sim 15 \%$ of the total ecosystem respiration. Bruhn et al. (2011) recently reported that GPP estimation after taking into account light inhibition on leaf respiration for the average day is $76 \%$ of the GPP estimation taken without consideration of reduction in leaf respiration due to illumination. Thus, accurate estimates of the GPP requires the inhibition of leaf dark respiration by light to be considered.

The Kok and Laisk methods are the two main methods used to estimate leaf day respiration. Kok (1948) analyzed the response of net photosynthesis rate to low light intensities and showed that the slope abruptly increases when the light intensity declines to the light compensation point - a phenomenon now known as the "Kok effect". Extrapolation of the linear section of the light response curve before the slope change to a light intensity of zero gives an estimate of $R_{\mathrm{L}}$. This technique has been widely used to analyze leaf respiration (Sharp et al. 1984, Villar et al. 1994, Bruhn et al. 2011). Laisk (1977) proposed a different $R_{\mathrm{L}}$ estimation method which was later extended by Brooks \& Farquhar (1985). Such method uses the response of $A_{n}$ to a series of low intercellular $\mathrm{CO}_{2}$ concentrations $\left(C_{\mathrm{i}}\right)$ with two or more varying light intensities. Then, the $\mathrm{CO}_{2}$ compensation point (at which the $\mathrm{CO}_{2}$ released from photorespiration equals the $\mathrm{CO}_{2}$ uptake by photosynthesis) and $R_{\mathrm{L}}$ are estimated by calculating the intersection points of the $A_{\mathrm{n}^{-}}$ $C_{\mathrm{i}}$ curves under different light intensities.

Based on the aforementioned methods, a number of experiments have been performed to study the degree of respiration inhibition by light in different plant species. Villar et al. $(1994,1995)$ found that the mean inhibition of $R_{\mathrm{L}}$ is $55 \%$ for two woody species, and that the light inhibition of respiration is greater in mature leaves $(81 \%)$ than in young leaves $(36 \%)$. Several studies further explored the variation in $R_{\mathrm{L}}$ associated with physiolo- 
gical factors, including photosynthetic rate, specific leaf area, leaf age and relative growth rate (Reddy et al. 1991, Villar et al 1995, Atkin et al. 1997, Reich et al. 1998), as well as environmental factors, namely, $\mathrm{CO}_{2}$ concentration, temperature, and drought (Bunce \& Ziska 1996, Nakaji et al. 2001, Peisker \& Apel 2001, Vose \& Ryan 2002, Warren \& Adams 2002, Tingey et al. 2007, Crous et al. 2011, Zou et al. 2011). However, our understanding of the inhibition of plant day respiration is still limited compared with that of night respiration, and the degree of light inhibition and the many variables that may influence it are not clear. This is particularly true for trees of temperate forests, in spite of their fundamental contribution to the global carbon budget.

In this study, the Kok and Laisk methods were used to estimate the leaf day respiration for three dominant tree species (Pinus koraiensis, Tilia amurensis and Fraxinus mandshurica) in the Changbai mountain forest which is a typical temperate natural forest in northeastern Asia. The major aim was to explore leaf respiration and the light inhibition degree of day respiration of evergreen conifer and deciduous broadleaved species in a temperate forest. Our findings may contribute to a better understanding of the biological processes of plant photosynthesis and respiration for the selected species, as well as to facilitate the accuracy of GPP estimates in temperate forests.

\section{Materials and Methods}

\section{Experimental field and plant materials}

The experiments were performed in the Changbai Mountain region of the Jilin pro- vince (northeastern China $-42^{\circ} 24^{\prime} \mathrm{N}, 128^{\circ}$ $06^{\prime} \mathrm{E}$; elevation: $738 \mathrm{~m}$ a.s.1.). This region has a humid subalpine climate, and the growing season is from May to September. The average annual temperature is $3.6{ }^{\circ} \mathrm{C}$ and the total precipitation $695 \mathrm{~mm}$. The soil is classified as dark brown forest soil.

Five-year-old saplings of three main tree species (P. koraiensis, T. amurensis, and $F$. mandshurica) were used in the experiment. The mean height of the potted saplings was $1.5 \mathrm{~m}$, and its averaged basal diameter was about $2 \mathrm{~cm}$. Data were collected from leaves of two deciduous broadleaved species ( $T$. amurensis, and F. mandshurica) and twoyears-old leaves of an evergreen conifer species (P. koraiensis).

\section{Measurements and data processing}

A portable photosynthesis system (LI6400, LI-COR, Lincoln, NE, USA) was used to measure the net photosynthetic rate $\left(A_{n}\right)$ of foliage under different photosynthetic photon flux density (PPFD) values and $\mathrm{CO}_{2}$ concentration levels. A $2 \times 3 \mathrm{~cm}$ cuvette was used in the gas-exchange measurements, with the flow rate set to $500 \mu \mathrm{mol} \mathrm{s} \mathrm{s}^{-1}$. During the measurements, leaf temperature and relative humidity were controlled at approx. $25{ }^{\circ} \mathrm{C}$ and $60 \%$, respectively. Measurements were taken from 08:00 to $12: 00$ on sunny days from July to September. For each treatment condition, three to four fully expanded and healthy representative leaves were randomly selected on saplings and considered as replicates. The sampled leaves were treated for each series gradient of PPFD values or $\mathrm{CO}_{2}$ concentrations under controlled optimal conditions using the portable photosynthesis system.

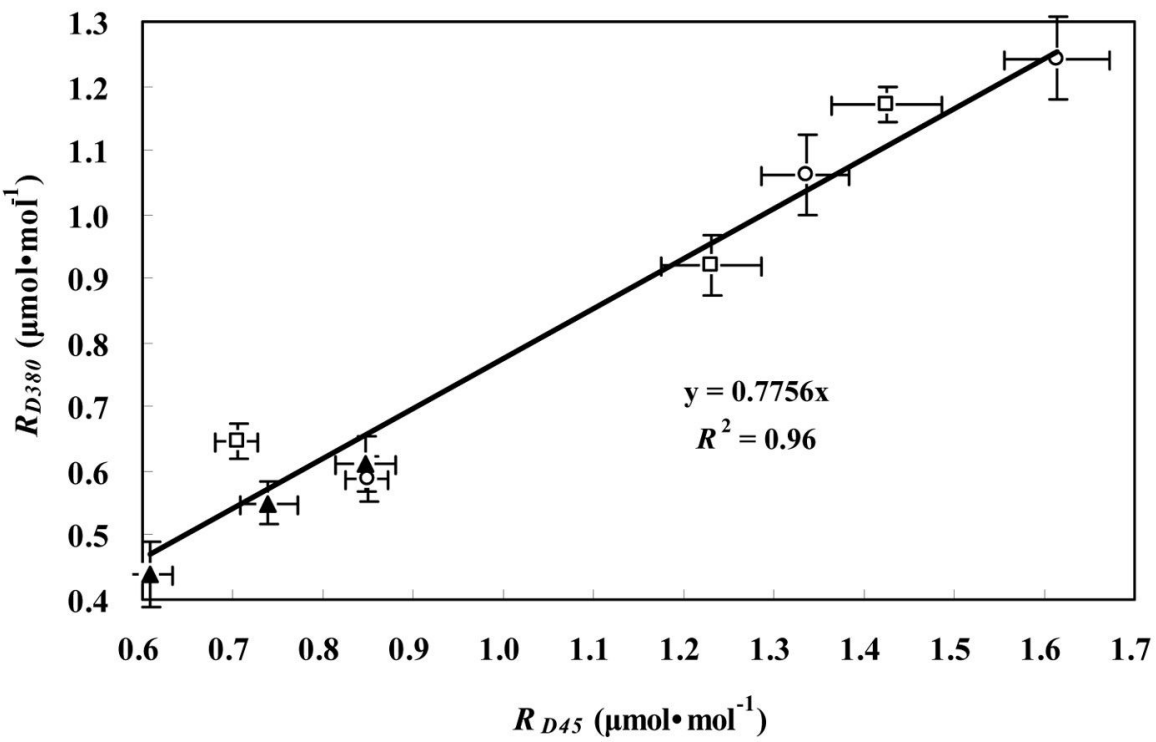

Fig. 1 - Relationship between $R_{\mathrm{D} 45}$ and $R_{\mathrm{D} 380}$ for the three tree species considered. $R_{\mathrm{D} 45}$ and $R_{\mathrm{D} 380}$ represent the leaf respiration in darkness measured at $\mathrm{CO}_{2}$ concentrations of $45 \mu \mathrm{mol}$ $\mathrm{mol}^{-1}$ and $380 \mu \mathrm{mol} \mathrm{mol}{ }^{-1}$, respectively, for $P$. koraiensis (black triangles), T. amurensis (white squares) and F. mandshurica (white circles). Data are presented as mean $\pm \mathrm{SD}$.
As for the Kok method, the sampled leaves were exposed to a range of PPFD values $(150,120,90,60,50,40,30,20,10,5$, and $\left.0 \mu \mathrm{mol} \mathrm{m} \mathrm{m}^{-2}\right)$ at a normal ambient $\mathrm{CO}_{2}$ con-

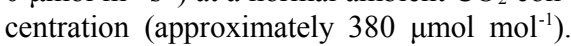
As for the Laisk method, each selected leaf was exposed to a series of $\mathrm{CO}_{2}$ concentrations $(150,120,90,70,60,50$, and $40 \mu \mathrm{mol}$ $\mathrm{mol}^{-1}$ ), and PPFD set at 50,100, and 150 $\mu \mathrm{mol} \mathrm{m} \mathrm{m}^{-2} \mathrm{~s}^{-1}$, respectively.

To compare $R_{\mathrm{L}}$ and night respiration $\left(R_{\mathrm{D}}\right)$, $R_{\mathrm{D}}$ measurements were conducted after 20 min of dark acclimation at $\mathrm{CO}_{2}$ concentration of 45 and $380 \mu \mathrm{mol} \mathrm{mol}^{-1}$ in order to determine differences in respiration under low and ambient $\mathrm{CO}_{2}$ condition. To determine the effect of light intensity on day respiration, seven PPFD levels $(50,100,150,210$, 300,600 , and $\left.800 \mu \mathrm{mol} \mathrm{m} \mathrm{m}^{-2} \mathrm{~s}^{-1}\right)$ and $\mathrm{CO}_{2}$ concentration series $(150,120,90,70,60$, 50 , and $40 \mu \mathrm{mol} \mathrm{mol}^{-1}$ ) were set for leaves of P. koraiensis in August and September. $A_{\mathrm{n}}$ was measured under different $\mathrm{CO}_{2}$ concentrations for each PPFD level. For each level of PPFD the linear regression of $A_{\mathrm{n}}$ over $C_{\mathrm{B}}$ was performed. $R_{\mathrm{L}}$ was estimated to be the value of the intercepted point of two regression lines established at each two ambient PPFD values. The measured data were then used to obtain $R_{\mathrm{L}}$ values by the Laisk method, and each $R_{\mathrm{L}}$ value corresponded to the averaged value of the two PPFD values. Additionally, determination for leaf nitrogen content was based on the Kjeldahl nitrogen method (Domini et al. 2009).

In the Kok method, the curve departed from a straight line when PPFD decreased to light compensation point. $R_{\mathrm{L}}$ was obtained by extrapolating the line to zero while ignoring the points below the light compensation point. Day respiration estimated by the Kok method was corrected based on Kirschbaum \& Farquhar (1987). In the Laisk method, linear regressions of the $A_{\mathrm{n}}-C_{\mathrm{i}}$ curves were obtained at three light levels, and the leaf dark respiration was estimated by the value of the point of intersection of those lines in the $A_{\mathrm{n}}$ coordinate. However, the Laisk method required the measurement to be carried out at very low $\mathrm{CO}_{2}$ concentration. To determine the effect of low $\mathrm{CO}_{2}$ concentrations on leaf respiration, the $\mathrm{CO}_{2}$ concentration was controlled at 45 or $380 \mu \mathrm{mol} \mathrm{mol}{ }^{-1}$ during $R_{\mathrm{D}}$ measurements for the three tree species. Fig. 1 shows the positive relationship between $R_{\mathrm{D} 45}$ and $R_{\mathrm{D} 380}$. The rates of $R_{\mathrm{D}}$ at low $\mathrm{CO}_{2}$ concentration were always higher than the corresponding values at high $\mathrm{CO}_{2}$ concentration. Their relationship was expressed by a linear equation following the suggestion of Villar et al. (1994, 1995 - eqn. 1):

$$
R_{D 380}=0.7756 \cdot R_{D 45}
$$

$\left(\mathrm{R}^{2}=0.96, \mathrm{P}<0.01\right)$ where $R_{\mathrm{D} 380}$ and $R_{\mathrm{D} 45}$ represent $R_{\mathrm{D}}$ in the ambient $\mathrm{CO}_{2}$ concentra- 
tion of 380 and $45 \mu \mathrm{mol} \mathrm{mol}^{-1}$, respectively. $R_{\mathrm{D} 380}$ was about $23 \%$ lower than $R_{\mathrm{D} 45}(\mathrm{P}<$ $0.05)$. Therefore, the respiration rate measured at low $\mathrm{CO}_{2}$ concentration was generally overestimated. A correction for leakage was necessary because it is hard to avoid $\mathrm{CO}_{2}$ exchange or leakage between the infrared gas analyzer (IRGA) chamber and the surrounding air (Pons \& Welschen 2002, Shapiro et al. 2004, Flexas et al. 2007, Rodeghiero et al. 2007). We corrected for $\mathrm{CO}_{2}$ leakage by diffusion in the Laisk method based on the following equation (eqn. 2) which was derived from the instruction manual of $\mathrm{Li}$-Cor Inc (2004):

$$
\frac{K}{u_{i}}=\frac{C_{S}-C_{R}}{C_{A}-C_{S}}
$$

where $K$ is the $\mathrm{CO}_{2}$ diffusion flow rate $(\mu \mathrm{mol}$ $\left.\mathrm{s}^{-1}\right)$, and $u_{\mathrm{i}}$ is the flow rate into the leaf chamber $\left.(\mu \mathrm{mol} \mathrm{s})^{-1}\right) . C_{\mathrm{S}}, C_{\mathrm{R}}$ and $C_{\mathrm{A}}$ indicates sample, reference and ambient $\mathrm{CO}_{2}$ concentration $\left(\mu \mathrm{mol} \mathrm{mol}^{-1}\right)$, respectively.

Statistical analysis was performed using SPSS ${ }^{\circledR}$ version 17.0 (SPSS, Chicago, IL, USA). Differences among the three species analyzed were tested by one-way ANOVA (Duncan test) for the parameter of $R_{\mathrm{L}}$ estimated independently by the Kok and the Laisk methods, $R_{\mathrm{D}}$, and degree of light inhibition of $R_{\mathrm{L}}$. Student's $t$-test was used to evaluate the differences between $R_{\mathrm{L}}$ estimated by the two above methods used, as well as the differences between $R_{\mathrm{L}}$ and $R_{\mathrm{D}}$ for the three tree species. Relationships were fitted with linear or polynomial functions which provided a simple and good description of the phenomenon. All the tests were based on a significance level of 0.05 .

\section{Results}

\section{Leaf dark respiration}

Fig. 2 and Fig. 3 show the $R_{\mathrm{L}}$ values obtained for the leaves of $P$. koraiensis by the Kok and the Laisk methods, respectively. The black arrow in Fig. 2 indicates the apparent rate of day respiration $\left(0.21 \mu \mathrm{mol} \mathrm{m} \mathrm{m}^{-2}\right.$ $\mathrm{s}^{-1}$ ). As for the Laisk method, three linear regressions of the $A_{\mathrm{n}}-C_{\mathrm{i}}$ curves intersected with each other within a centralized triangle range (Fig. 3). The central point (marked with red square in Fig. 3) represents the mean value of the three intersections of the triangle extended to the $A_{\mathrm{n}}$ axis and provides the value of day respiration. The intersection of the three lines obtained using the Laisk method formed a triangle instead of being a single point. The apparent lack of convergence of the three lines might result from measurement error arising from $\mathrm{CO}_{2}$ leak through the gaskets or from the influence of the respired $\mathrm{CO}_{2}$ on the leaf under the gaskets. Therefore, the day respiration rates estimated by the Kok and the Laisk methods were corrected. As for the Kok method, the corrected values

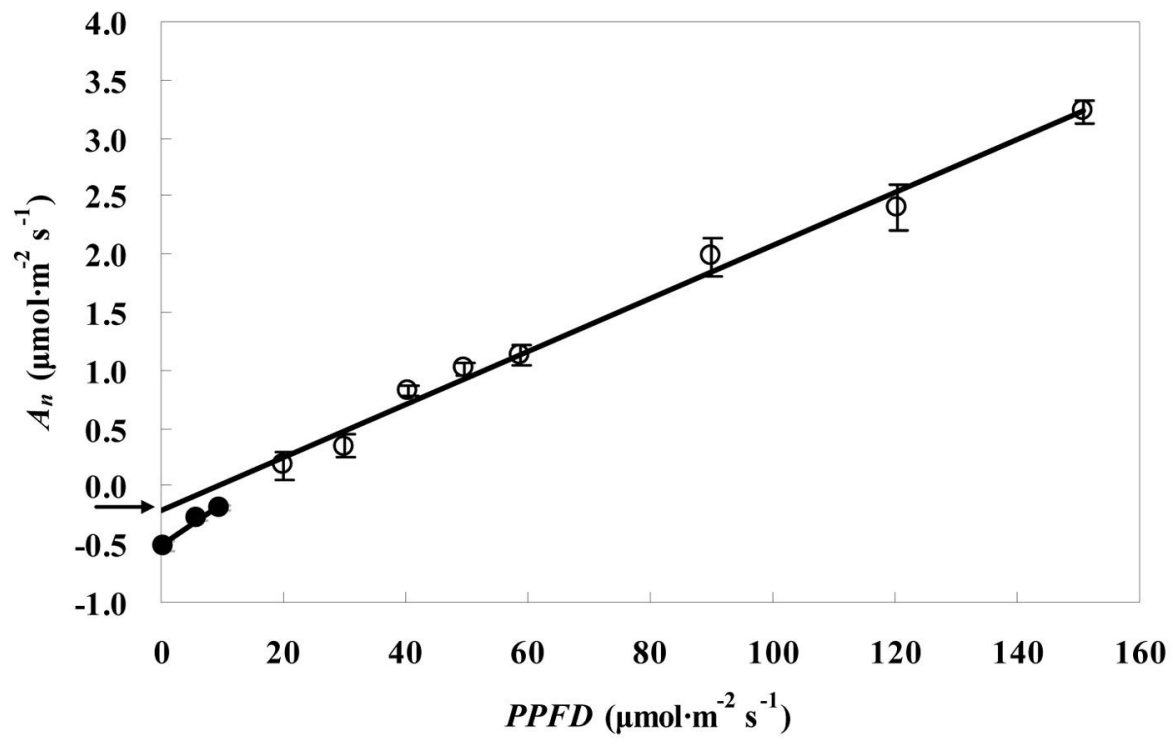

Fig. 2 - Linear relationship between the net $\mathrm{CO}_{2}$ assimilation rate $\left(A_{\mathrm{n}}\right)$ and low PPFD values (Kok method) for P. koraiensis saplings in the Changbai station in July. The slope of the regression line of black circles $\left(\mathrm{R}^{2}=0.98, P<0.05\right)$ is higher than that of the linear regression line of white circles $\left(\mathrm{R}^{2}=0.91, P<0.05\right)$. Arrow indicates the value of day respiration. Data are presented as mean $\pm \mathrm{SD}$.

of day respiration $\left(R_{\mathrm{LK}}\right)$ were $18 \%$ higher $(\mathrm{P}$ $<0.05)$ than the apparent values, while for the Laisk method, the corrected values of day respiration $\left(R_{\mathrm{LL}}\right)$ decreased $22 \%(\mathrm{P}<$ $0.05)$ compared with the apparent values. Tab. 1 showed the $R_{\mathrm{L}}$ values estimated by the Kok and the Laisk methods for the three tree species during the peak growing season. On

average, $R_{\mathrm{LK}}$ values obtained for the evergreen conifer ( $P$. koraiensis) were $31.7 \%$ lower $(\mathrm{P}<0.05)$ while the $R_{\mathrm{LL}}$ values was $36.8 \%$ lower $(\mathrm{P}<0.05)$ than those obtained for the deciduous broadleaved trees $(T$. amurensis and $F$. mandshurica). The difference between $R_{\mathrm{LK}}$ and $R_{\mathrm{LL}}$ values was about $4 \%$ for the three tree species.

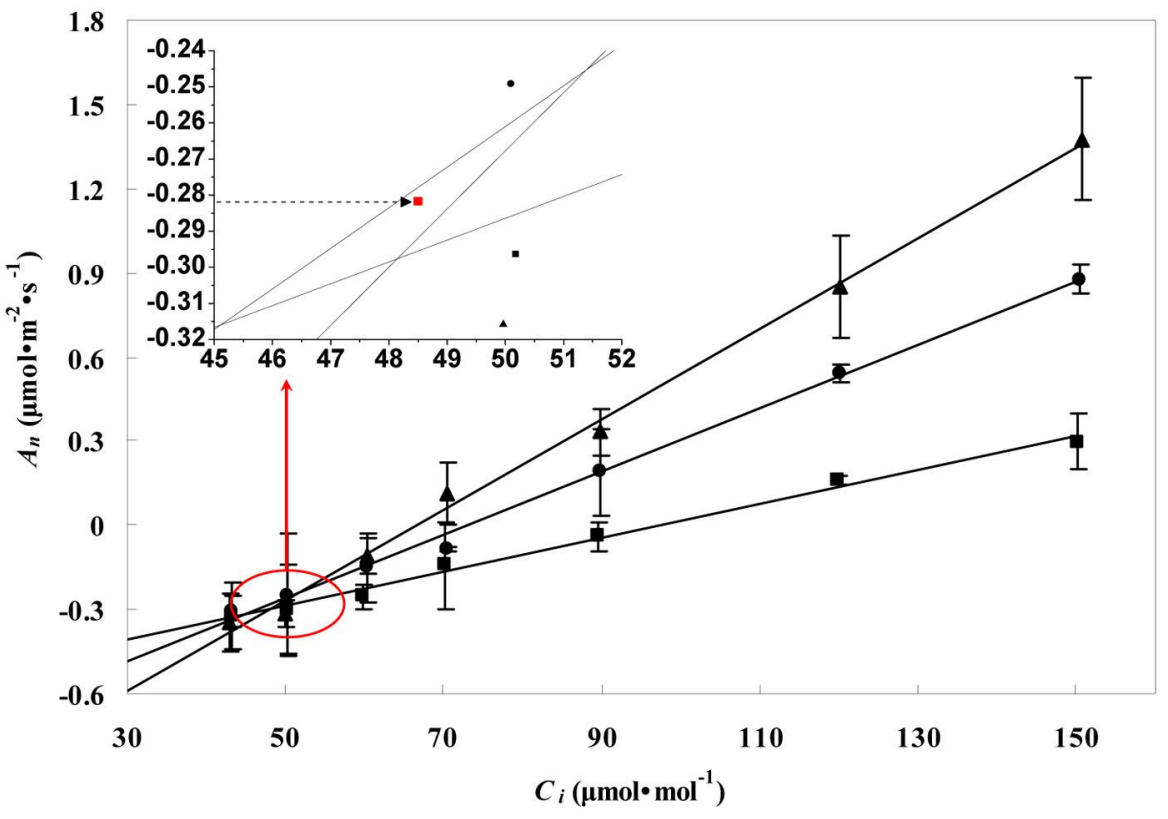

Fig. 3 - Linear regressions of the net $\mathrm{CO}_{2}$ assimilation rate $\left(A_{\mathrm{n}}\right) v s$. the intercellular $\mathrm{CO}_{2}$ concentrations $\left(C_{\mathrm{i}}\right)$ at three PPFD values of 50 (black squares), 100 (black circles), and 150 (black triangles) $\mu \mathrm{mol} \mathrm{m} \mathrm{m}^{-2} \mathrm{~s}^{-1}$ for leaves of $P$. koraiensis saplings in the Changbai Mountain in July (Laisk method). Day respiration value was calculated as the barycenter (the dotted arrow pointed) of the triangle formed by the intersection of the three lines. Data are presented as mean $\pm \mathrm{SD}$. 
Tab. 1 - Leaf day respiration $R_{\mathrm{L}}\left(R_{\mathrm{LK}}\right.$ and $\left.R_{\mathrm{LL}}\right)$ and night respiration $R_{\mathrm{D}}\left(\mu \mathrm{mol} \cdot \mathrm{m}^{-2} \cdot \mathrm{s}^{-1}\right)$ for the leaves of the three species studied ( $P$. koraiensis, $T$. amurensis and $F$. mandshurica) from July to September 2011. Data are presented as mean \pm residual standard deviation (RSD) for $R_{\mathrm{LK}}$ and $R_{\mathrm{LL}}$, and mean $\pm \mathrm{SD}$ for $R_{\mathrm{D}} . R_{\mathrm{LK}}$ and $R_{\mathrm{LL}}$ are leaf day respiration values estimated by the Kok method and the Laisk method, respectively. (*): RSD of $R_{\mathrm{LL}}$ was calculated by averaging the RSD values of three linear regressions.

\begin{tabular}{llccc}
\hline \multirow{2}{*}{ Species } & \multirow{2}{*}{ Month } & \multicolumn{2}{c}{$\boldsymbol{R}_{\mathbf{L}}$} & \multirow{2}{*}{$\boldsymbol{R}_{\mathbf{D}}$} \\
\cline { 3 - 4 } & & $\boldsymbol{R}_{\mathbf{L K}}$ & $\boldsymbol{R}_{\mathbf{L L}}$ & \\
\hline Pinus & July & $0.26 \pm 0.0113$ & $0.22 \pm 0.0309$ & $0.44 \pm 0.1208$ \\
koriaensis & August & $0.28 \pm 0.0267$ & $0.42 \pm 0.0395$ & $0.61 \pm 0.0737$ \\
& September & $0.22 \pm 0.0277$ & $0.18 \pm 0.0371$ & $0.55 \pm 0.1071$ \\
\hline Tilia & July & $0.33 \pm 0.0261$ & $0.35 \pm 0.0699$ & $0.65 \pm 0.0924$ \\
amurensis & August & $0.52 \pm 0.0407$ & $0.59 \pm 0.0294$ & $1.17 \pm 0.1104$ \\
& September & $0.31 \pm 0.0599$ & $0.29 \pm 0.0472$ & $0.92 \pm 0.1269$ \\
\hline Fraxinus & July & $0.30 \pm 0.0362$ & $0.36 \pm 0.0818$ & $0.59 \pm 0.0640$ \\
mandshurica & August & $0.56 \pm 0.0278$ & $0.59 \pm 0.0529$ & $1.24 \pm 0.1593$ \\
& September & $0.31 \pm 0.0256$ & $0.33 \pm 0.0680$ & $1.06 \pm 0.1467$ \\
\hline
\end{tabular}

Also, the $R_{\mathrm{D}}$ value of the conifer was lower than those of the deciduous trees (Tab. 1), and the averaged $R_{\mathrm{D}}$ values for the conifer over the whole study period were $40.7 \%$ lower $(\mathrm{P}<0.05)$ than those obtained for the broadleaves. As displayed in Fig. 4, a significant positive correlation was found between $R_{\mathrm{D}}$ and $R_{\mathrm{L}}$ estimated by the Kok $\left(\mathrm{R}^{2}=0.70, \mathrm{P}<0.05\right)$ and the Laisk methods $\left(\mathrm{R}^{2}=0.57, \mathrm{P}<0.05\right)$. The differences between $R_{\mathrm{L}}$ and $R_{\mathrm{D}}$ were significant for all three tree species $(\mathrm{P}<0.05)$.

\section{Relationship between day respiration} and leaf nitrogen content

The average leaf $\mathrm{N}$ concentration for the evergreen conifer tree $(P$. koraiensis) was $27.1 \%$ lower $(\mathrm{P}<0.05)$ than for the two deciduous broadleaved trees ( $F$. mandshurica
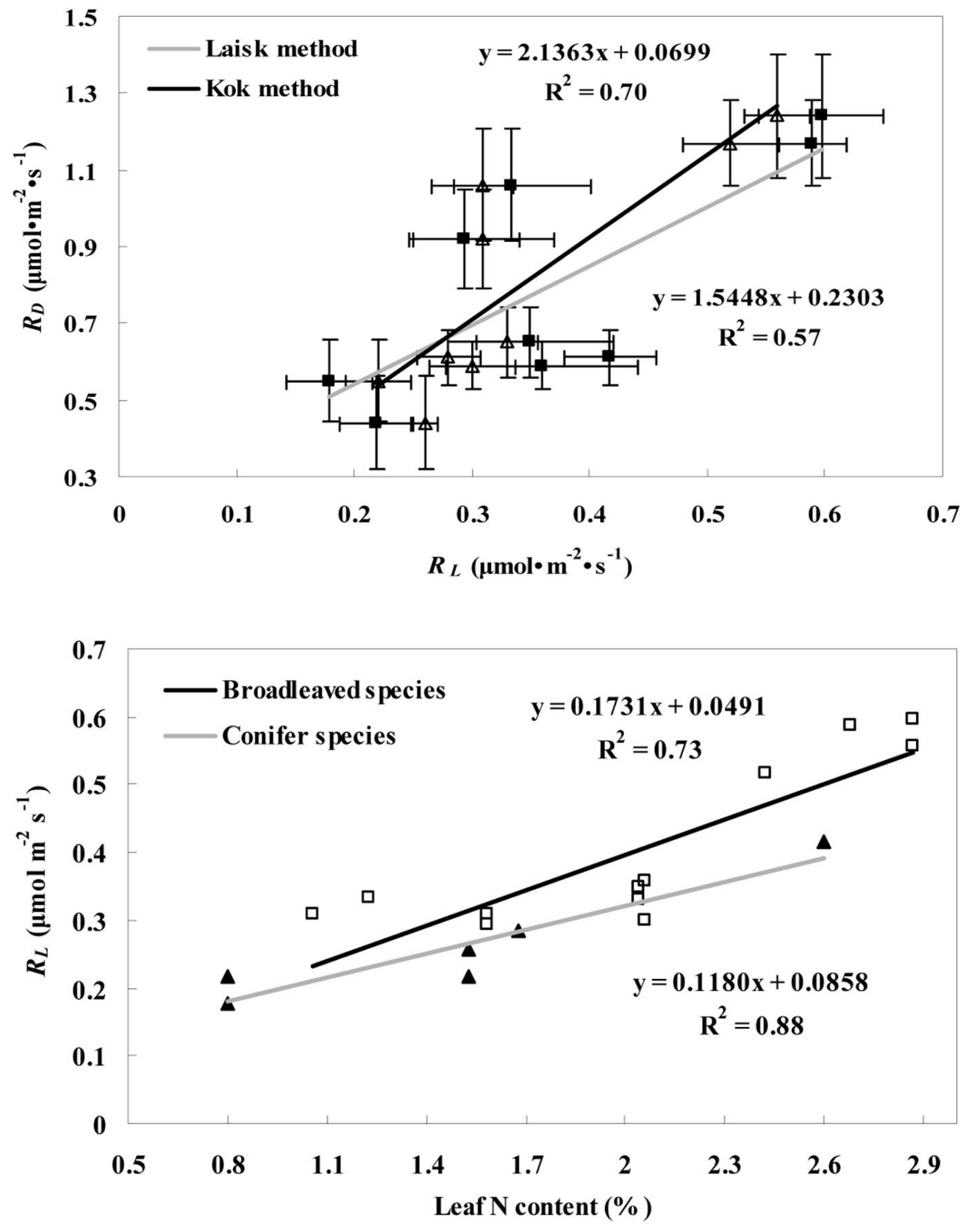

Fig. 4 - Relationship between $R_{\mathrm{D}}$ and $R_{\mathrm{L}}$ values estimated by Kok ( $R_{\mathrm{LK}}$ - triangles) and Laisk methods ( $R_{\mathrm{LL}}$ - squares) for the three tree species (P. koraiensis, T. amurensis, and $F$. mandshurica). Linear relationship estimated by the Kok and the Laisk method is represented with the black and gray line, respectively.
Fig. 5 - Variation in $R_{\mathrm{L}}$ with leaf nitrogen content for the two deciduous broadleaved species (white squares) and one evergreen conifer species (black triangles). The linear regression for broadleaved species and conifer species was showed with the black and gray line, respectively. $R_{\mathrm{L}}$ represents the leaf day respiration which includes the value estimated by the $\operatorname{Kok}\left(R_{\mathrm{LK}}\right)$ and Laisk methods $\left(R_{\mathrm{LL}}\right)$ from July to September. 


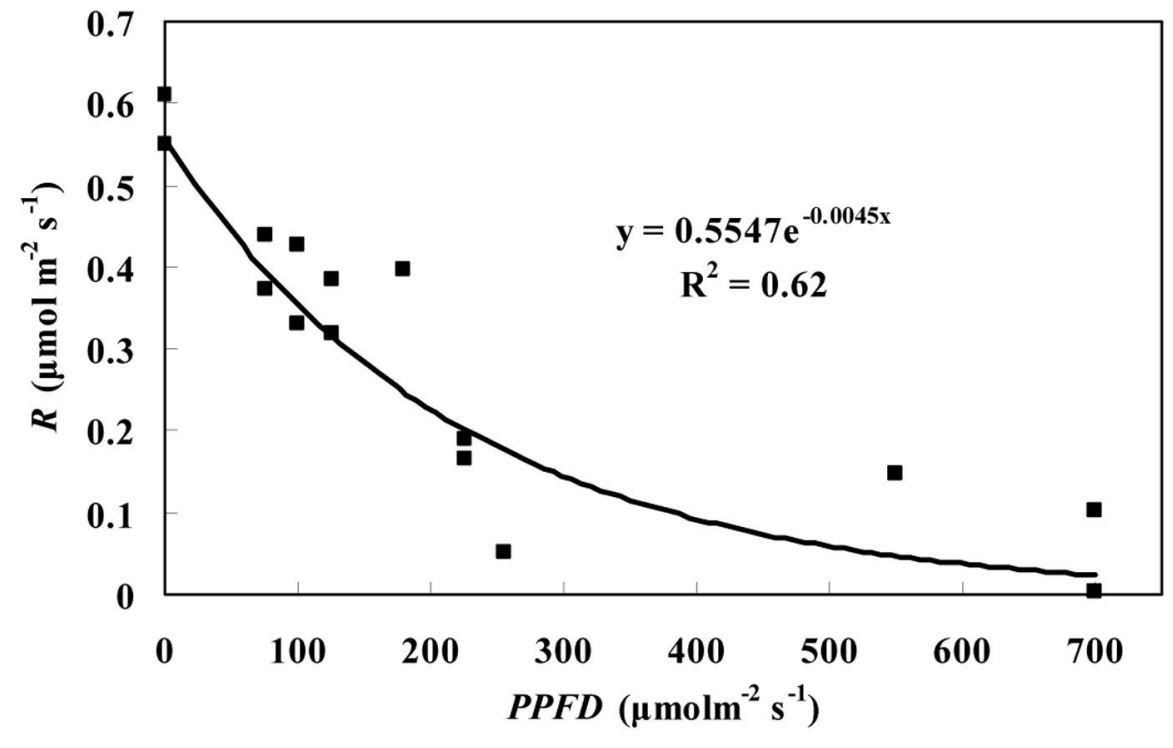

Fig. 6 - The effects of light on leaf dark respiration. Leaf dark respiration $(R)$, including day respiration estimated by the Laisk method and night respiration, of $P$. koraiensis at different PPFD values in August and September.

and T. amurensis). Moreover, a strong positive correlation between leaf nitrogen content and day respiration was found (Fig. 5). The correlation between $R_{\mathrm{L}}$ and leaf nitrogen content is expressed as eqn. 3 for the conifer species $\left(\mathrm{R}^{2}=0.88, \mathrm{P}<0.05\right)$ and as eqn. 4 $\left(\mathrm{R}^{2}=0.73, \mathrm{P}<0.05\right)$ for the broadleaved species:

$$
\begin{aligned}
& R_{L e c}=0.1180 \cdot N+0.0858 \\
& R_{L d b}=0.1731 \cdot N+0.0491
\end{aligned}
$$

where $R_{\mathrm{Lec}}$ and $R_{\mathrm{Ldb}}$ are the day respiration rates of the evergreen conifer species and two deciduous broadleaved trees, respectively, and $N$ is the leaf nitrogen content.

\section{Light inhibition of day respiration}

The average $R_{\mathrm{L}}$ inhibition of the three tree species was found to be $55.9 \%$ and $52.6 \%$ for the Kok and Laisk methods, respectively. No significant differences were observed among the three tree species in the light inhibition on $R_{\mathrm{L}}$. The degree of light inhibition on $R_{\mathrm{L}}$ was different under different PPFD values. Based on our data, the relationship between $R$ and PPFD can be described by the following exponential equation (eqn. 5):

$$
R=0.5547 \cdot e^{-0.0045 \cdot P P F D}
$$

$\left(\mathrm{R}^{2}=0.62, \mathrm{P}<0.05\right)$ where $R$ is the leaf dark respiration, including both leaf dark respiration in light and darkness. As shown in Fig. 6 , the value of $R$ for $P$. koraiensis was the highest in darkness, and then $R$ decreased rapidly following an increase in the incident PPFD. The decrease rate of $R$ gradually de- clined with PPFD increase until it remained constant.

\section{Discussion}

The corrected day respiration was $18 \%$ higher and $22 \%$ lower than the apparent values obtained by the Kok and the Laisk methods, respectively. Kirschbaum \& Farquhar (1987) showed that $R_{\mathrm{L}}$ measured by the Kok method is underestimated because it is assumes that the $C_{\mathrm{i}}$ values remain constant with changing PPFD. However, it has been shown that when PPFD decreases, stomatal closure is altered in response to environmental changes (Tcherkez et al. 2008), and $C_{\mathrm{i}}$ gradually increases because of the decreased stomatal conductance. Consequently, a fraction of the respired $\mathrm{CO}_{2}$ is not promptly released and remains involved in the photosynthesis process. This results in an increase in $A_{\mathrm{n}}$ values and a decline in the slope of regression of $A_{\mathrm{n}} v s$. PPFD (Kirschbaum \& Farquhar 1987, Villar et al. 1994), which accounts for the underestimation of $R_{\mathrm{L}}$ in the Kok method. $R_{\mathrm{LL}}$ was overestimated in the Laisk method as the measurement must be conducted at low $\mathrm{CO}_{2}$ concentration. Some studies have proposed that the overestimation of $R_{\mathrm{LL}}$ is caused by the $\mathrm{CO}_{2}$ acting as an inhibitor of certain enzymes (Brooks \& Farquhar 1985, Kirschbaum \& Farquhar 1987, Tjoelker et al. 2001). However, a large number of studies suggest that leaf respiration changes with $\mathrm{CO}_{2}$ possibly due to small leaks or diffusion in the gas exchange measurement systems (Amthor et al. 2001, Pons

\section{Uncertainties in day respiration estimate}

\& Welschen 2002, Shapiro et al. 2004, Flexas et al. 2007, Rodeghiero et al. 2007). Therefore, in this study $R_{\mathrm{LL}}$ was corrected based on the method suggested by Li-Cor Inc (2004) to compensate the $\mathrm{CO}_{2}$ leakage in the Laisk method.

\section{Differences between dark respiration of} broadleaved and conifer species

Consistent with several previous studies (Villar et al. 1995, Atkin et al. 1997), $R_{\mathrm{L}}$ was found in this investigation to be positively correlated with $R_{\mathrm{D}}$. Both $R_{\mathrm{L}}$ and $R_{\mathrm{D}}$ of the deciduous broadleaved species were higher than those of the conifer species. In addition, Cornelissen et al. (1999) reported a growth rate of deciduous broadleaved species higher than that of the conifer species. $R_{\mathrm{L}}$ and $R_{\mathrm{D}}$ were higher in the rapidly growing tree species, likely because rapid-growth species generally require more carbon skeletons, energy and reductant-producing organelles, which were derived from the respiration process in tree species (Amthor 1989, Villar et al. 1995, Lambers et al. 1996, Atkin et al. 1997). Atkin et al. (1997) also reported that $R_{\mathrm{L}}$ and $R_{\mathrm{D}}$ were positively correlated with $A_{\mathrm{n}}$ and the relative growth rate in Poa species. Hence, greater values of $R_{\mathrm{L}}$ and $R_{\mathrm{D}}$ can be hypothesized to occur in fast-growing plants. Wang et al. (2001) also has suggested that higher biomass production in fast-growing species demand greater respiration production, and this requirement is fulfilled by higher $R_{\mathrm{L}}$ and $R_{\mathrm{D}}$ values. A positive correlation between $R_{\mathrm{L}}$ and leaf $\mathrm{N}$ concentration was also found in our study, which is consistent with several previous reports on a positive correlation between plant respiration and the leaf $\mathrm{N}$ concentration (Amthor 1989, Ryan 1991). Furthermore, we found that leaf $\mathrm{N}$ concentration in $P$. koraiensis was lower than in F. mandshurica and T. amurensis. This is consistent with previous reports by Reich et al. (1992) and Villar et al. (1995) showing that the leaf $\mathrm{N}$ concentration is lower in evergreen species than in deciduous species.

\section{Light inhibition of day respiration}

In this study, $R_{\mathrm{L}}$ was significantly lower than $R_{\mathrm{D}}$ for the three tree species, indicating that $R_{\mathrm{L}}$ was inhibited by light. This result is in agreement with those of several previous studies (Sharp et al. 1984, Brooks \& Farquhar 1985, McCashin et al. 1988, Hanning $\&$ Heldt 1993, Tcherkez et al. 2005). Some studies have suggested that inhibition of leaf dark respiration in light is only apparent and possibly results from internal $\mathrm{CO}_{2}$ re-fixation. Loreto et al. (2001) and Pinelli \& Loreto (2003) found that $R_{\mathrm{L}}$ and $R_{\mathrm{L}} / R_{\mathrm{D}}$ were inversely correlated with photosynthesis, and suggested that most of the respiratory $\mathrm{CO}_{2}$ was re-fixed by photosynthesis. Pinelli \& Loreto (2003) also reported that the sum of 
re-fixed and emitted ${ }^{12} \mathrm{CO}_{2}$ was close to mitochondrial respiration in the dark. However, the authors also suggested that mitochondria respiration may be inhibited in light when the leaf is in salt- and water-stressed condition, because the sum of re-fixed and emitted ${ }^{12} \mathrm{CO}_{2}$ under the above conditions was lower than that in the dark. Furthermore, Pärnik \& Keerberg (1995) stated that leaf $R_{\mathrm{L}}$ is lower than $R_{\mathrm{D}}$ in light even when the re-fixed respiratory $\mathrm{CO}_{2}$ is taken into consideration. Additionally, many studies have suggested that the inhibition in light may be due to inhibition of respiratory enzymes by co-factors such as ATP and NADPH (Graham 1980, McCashin et al. 1988). Tcherkez et al (2005) showed that the inhibition mainly occurred during the Krebs cycle and the inhibition in the Krebs cycle was reduced by $95 \%$ in light, while the pyruvate dehydrogenase was reduced by only $27 \%$. The reduction in the Krebs cycle, which is one of the most important processes of leaf respiration, oc curs mainly because some enzymes are inhibited by the high ratio of NADPH/NADP+ in light (Siedow \& Day 2000). Likewise, it has been suggested that high NADPH/ NADP+ ratios could also inhibit isocitrate dehydrogenase in illuminated mitochondria (Igamberdiev \& Gardeström 2003). Thus, there is considerable evidence supporting that day respiration is indeed inhibited in light. In this study, no significant differences were found in the light inhibition of $R_{\mathrm{L}}$ between broadleaved and conifer trees, in spite of their different photosynthetic capacities and relative growth rates. Therefore, light inhibition on $R_{\mathrm{L}}$ may not be correlated with $A_{\mathrm{n}}$ or relative growth rate. This conclusion is consistent with results reported by Atkin et al. (1997)

Our results showed that leaf dark respiration varied under different PPFD levels. The relationship between $R_{\mathrm{L}}$ and PPFD showed in Fig. 6 is consistent with that obtained in previous studies (Brooks \& Farquhar 1985, Villar et al. 1994, 1995) by the Laisk method. The photosynthetic rate generally increases with increasing PPFD, but the rate of increase gradually declines. In this study, $R_{\mathrm{L}}$ was found to decrease with increasing PPFD, likely because more ATP and $\mathrm{NADPH}$ were available for increasing the photosynthetic rate (Turpin \& Weger 1990), causing the energy demand to step up gradually from $R_{\mathrm{L}}$ to plateau (Villar et al. 1995).

Both the comparison of $R_{\mathrm{L}}$ and $R_{\mathrm{D}}$ of the three tree species and the analysis of the relationship between $R$ and PPFD demonstrated a remarkable inhibition of the day respiration. Peisker \& Apel (2001) reported that the ratio of $R_{\mathrm{L}}$ to $R_{\mathrm{D}}$ ranges from 30 to $100 \%$. However, Hurry et al. (1996) concluded that $R_{\mathrm{L}}$ is higher in light than in darkness in rye using the ${ }^{14} \mathrm{C}$-labeling measurement technique. Additionally, Zaragoza-Castells et al.
(2007) found that $R_{\mathrm{L}}$ is inhibited in light only under certain conditions. Thus, $R_{\mathrm{L}}$ inhibition in light may not occur in all species and under all conditions. Light inhibition of $R_{\mathrm{L}}$ and the degree of inhibition of $R_{\mathrm{L}}$ may depend on the species and growth conditions. Hence, additional studies on various species and under different environmental conditions are needed to obtain a deeper understanding of the above physiological processes. Variations in $R_{\mathrm{L}}$ with change in PPFD and $\mathrm{CO}_{2}$ concentration were analyzed in this investigation. However, many other factors affecting $R_{\mathrm{L}}$ may exist, so further studies should be carried out to fully understand the mechanism by which $R_{\mathrm{L}}$ is inhibited in light.

\section{Conclusions}

In summary, our findings revealed that $R_{\mathrm{LK}}$ and $R_{\mathrm{LL}}$ in conifer trees were lower by $31.7 \%$ and $36.8 \%$, respectively, than those in broadleaved trees considered in this study. We detected no significant difference in light inhibition of respiration between the coniferous and the broadleaved tree species. The average $R_{\mathrm{L}}$ inhibition in the three tree species was $55.9 \%$ and $52.6 \%$ for $R_{\mathrm{LK}}$ and $R_{\mathrm{LL}}$ values, respectively, relative to $R_{\mathrm{D}}$. $R_{\mathrm{L}}$ was found to be positively correlated with $R_{\mathrm{D}}$ in the three tree species. $R_{\mathrm{L}}$ also decreased with increasing PPFD, but the decrease rate of $R_{\mathrm{L}}$ gradually declined. These findings may be useful in estimating the component of carbon exchange and carbon budget (e.g., $R_{\mathrm{e}}, \mathrm{NEE}$, GPP) of the forest ecosystem by evaluating the light inhibition of respiration in the representative tree species.

\section{Acknowledgments}

We are deeply grateful to all the staff of the National Forest Ecosystem Research Station of Changbai Mountain for their assistance in the maintenance of instruments and collection of field data. We sincerely thank Dr. M. Kirschbaum for providing the program for correcting the $R_{\mathrm{L}}$ values estimated by the Kok method. This study was supported by the National Science Foundation of China (no. 41375119), the State Key Laboratory of Forest and Soil Ecology (no. LFSE2013-11) and the Youth Fund for Creative Research Groups, Institute of Applied Ecology, CAS.

\section{References}

Amthor JS (1989). Respiration and crop productivity. Spinger-Verlag, New York, USA, pp. 215. - doi: 10.1007/978-1-4615-9667-7

Amthor JS (2000). The McCree-de Wit-Penning de Vries-Thornley respiration paradigms: 30 years later. Annals of Botany 86: 1-20. - doi: 10.1006/anbo.2000.1175

Amthor JS, Koch GW, Willms JR, Layzell DB (2001). Leaf $\mathrm{O}_{2}$ uptake in the dark is independent of coincident $\mathrm{CO}_{2}$ partial pressure. Journal of Experimental Botany 52: 2235-2238. - doi: $10.1093 /$ jexbot/52.364.2235
Atkin OK, Botman B, Lambers H (1996). The causes of inherently slow growth in alpine plants: an analysis based on the underlying carbon economies of alpine and lowland Poa species. Functional Ecology 10: 698-707. - doi: $10.2307 / 2390504$

Atkin OK, Westbeek MHM, Cambridge ML, Lambers H, Pons TL (1997). Leaf respiration in light and darkness (a comparison of slow-and fast-growing Poa species). Plant Physiology 113: 961-965. [online] URL: http://www.plantphysiol. org/content/113/3/961.short

Ayub G, Smith RA, Tissue DT, Atkin OK (2011). Impacts of drought on leaf respiration in darkness and light in Eucalyptus saligna exposed to industrial-age atmospheric $\mathrm{CO}_{2}$ and growth temperature. New Phytologist 190: 1003-1018. - doi: 10.1111/j.1469-8137.2011.03673.x

Brooks A, Farquhar GD (1985). Effect of temperature on the $\mathrm{CO}_{2} / \mathrm{O}_{2}$ specificity of Ribulose-1.5bisphosphate carboxylase oxygenase and the rate of respiration in the light-estimates from gas-exchange measurements on spinach. Planta 165: 397-406. - doi: 10.1007/BF00392238

Bruhn D, Mikkelsen TN, Herbst M, Kutsch WL, Ball MC, Pilegaard K (2011). Estimating daytime ecosystem respiration from eddy-flux data. Biosystems 103: 309-313. - doi: 10.1016/j.bio systems.2010.10.007

Bunce JA, Ziska LH (1996). Responses of respiration to increases in carbon dioxide concentration and temperature in three soybean cultivars. Annals of Botany 77: 507-514. - doi: 10.1006/anbo. 1996.0061

Collier DE, Cummins WR, Villar R (1992). Diurnal patterns of respiration in the leaves of four forest tree species. Physiologia Plantarum 84: 361-366. - doi: 10.1111/j.1399-3054.1992.tb046 76.x

Cornelissen JH, Pérez-Harguindeguy N, Díaz S, Grime JP, Marzano B, Cabido M, Vendramini F, Cerabolini B (1999). Leaf structure and defence control litter decomposition rate across species and life forms in regional floras on two continents. New Phytologist 143: 191-200. - doi: 10.1046/j.1469-8137.1999.00430.x

Crous KY, Zaragoza-Castells J, Löw M, Ellsworth DS, Tissue DT, Tjoelker MG, Barton CVM, Gimeno TE, Atkin OK (2011). Seasonal acclimation of leaf respiration in Eucalyptus saligna trees: impacts of elevated atmospheric $\mathrm{CO}_{2}$ and summer drought. Global Change Biology 17: 1560-1576. - doi: 10.1111/j.1365-2486.2010.02 325.x

Domini C, Vidal L, Cravotto G, Canals A (2009). A simultaneous, direct microwave/ultrasoundassisted digestion procedure for the determination of total Kjeldahl nitrogen. Ultrasonics sonochemistry 16: 564-569. - doi: 10.1016/j.ultsonch. 2008.12.006

Flexas J, Díaz-Espejo A, Berry JA, Cifre J, Galmés J, Kaldenhoff R, Medrano H, Ribas-Carbó M (2007). Analysis of leakage in IRGA's leaf chambers of open gas exchange systems: quantification and its effects in photosynthesis parameterization. Journal of Experimental Botany 
58: 1533-1543. - doi: 10.1093/jxb/erm027 Graham D (1980). Effects of light on "dark" respiration. In: "Biochemistry of Plants" (vol. 2) Academic Press, New York, USA, pp. 525-579.

Hanning I, Heldt HW (1993). On the function of mitochondrial metabolism during photosynthesis in spinach (Spinacia oleracea L.) leaves. Plant physiology 103: 1147-1154. [online] URL: http://www.plantphysiol.org/content/103/4/1147. short

Hoefnagel MHN, Atkin OK, Wiskich JT (1998). Interdependence between chloroplasts and mitochondria in the light and dark. Biochimica et biophysica acta Bioenergetics 1366: 235-255. doi: 10.1016/S0005-2728(98)00126-1

Hurry V, Keerberg O, Parnik T, Oquist G, Gardestrom P (1996). Effect of cold hardening on the components of respiratory decarboxylation in the light and in the dark in leaves of winter rye. Plant Physiology 111: 713-719. [online] URL: http://www.plantphysiol.org/content/111/3/713.s hort

Igamberdiev AU, Gardeström P (2003). Regulation of NAD- and NADP- dependent isocitrate dehydrogenases by reduction levels of pyridine nucleosides in mitochondria and cytosol of Pea leaves. Biochimica Biophysica Acta-Bioenergetics 1606: 117-125. - doi: 10.1016/S0005-2728 (03)00106-3

Janssens IA, Lankreijer H, Matteucci G, Kowalski AS, Buchmann N, Epron D, Pilegaard K, Kutsch W, Longdoz B, Grünwald T, Montagnani L, Dore S, Rebmann C, Moors EJ, Grelle A, Rannik U, Morgenstern K, Oltchev S, Clement R, Guomundsson J, Minerbi S, Berbigier P, Ibrom A, Moncrieff J, Aubinet M, Bernhofer C, Jensen O, Vesala T, Granier A, Schulze ED, Lindroth A, Dolman AJ, Jarvis PG, Ceulemans R, Valentini R (2001). Productivity overshadows temperature in determining soil and ecosystem respiration across European forests. Global Change Biology 7: 269-278. - doi: 10.1046/j.1365-2486.2001.00 412.x

Kirschbaum MUF, Farquhar GD (1987). Investigation of the $\mathrm{CO}_{2}$ dependence of quantum yield and respiration in Eucalyptus pauciflora. Plant physiology 83: 1032-1036. [online] URL: http://www.plantphysiol.org/content/83/4/1032.s hort

Kok B (1948). A critical consideration of the quantum yield of Chlorella-photosynthesis. Junk, Amsterdam, The Netherlands, pp. 56.

Kromer S (1995). Respiration during photosynthesis. Annual Review of Plant Biology 46: 45-70. doi: 10.1146/annurev.pp.46.060195.00040 1

Laisk AK (1977). Kinetika fotosinteza $i$ fotodykhaniya Ca-rastenii [Kinetics of photosynthesis and photorespiration in $\mathrm{C}_{3}$ plants]. A \& OJA, Nauka, Moscow, Russia. [in Russian]

Lambers H, Atkin OK, Scheurwater I (1996). Respiratory patterns in roots in relation to their functioning. Plant Roots. The Hidden Half. Marcel Dekker Inc, New York, USA, pp. 323-362.

Li-Cor Inc (2004). Using the LI-6400 Portable photosynthesis system (version 6). Li-Cor Inc, Lincoln, NE, USA, pp. 48-49.
Loreto F, Velikova V, Di Marco G (2001). Respiration in the light measured by ${ }^{12} \mathrm{CO}_{2}$ emission in ${ }^{13} \mathrm{CO}_{2}$ atmosphere in maize leaves. Australian Journal of Plant Physiology 28: 1103-1108. [online] URL: http://www.publish.csiro.au/?paper= PP01091

McCashin BG, Cossins EA, Canvin DT (1988). Dark respiration during photosynthesis in wheat leaf slices. Plant physiology 87: 155-161. [online] URL: http://www.plantphysiol.org/content/ 87/1/155.short

Nakaji T, Fukami M, Dokiya Y, Izuta T (2001). Effects of high nitrogen load on growth, photosynthesis and nutrient status of Cryptomeria japonica and Pinus densiflora seedlings. Trees Structure and Function 15: 453-461. - doi: 10.10 07/s00468-001-0130-x

Pärnik T, Keerberg O (1995). Decarboxylation of primary and end products of photosynthesis at different oxygen concentrations. Journal of Experimental Botany 46: 1439-1477. - doi: 10.1093 /jxb/46.special issue. 1439

Peisker M, Apel H (2001). Inhibition by light of $\mathrm{CO}_{2}$ evolution from dark respiration: Comparison of two gas exchange methods. Photosynthesis Research 70: 291-298. - doi: 10.1023/A:1014 799118368

Pinelli P, Loreto F (2003). ${ }^{12} \mathrm{CO}_{2}$ emission from different metabolic pathways measured in illuminated and darkened $\mathrm{C}_{3}$ and $\mathrm{C}_{4}$ leaves at low, atmospheric and elevated $\mathrm{CO}_{2}$ concentration. Journal of Experimental Botany 54: 1761-1769. doi: $10.1093 / \mathrm{jxb} / \mathrm{erg} 187$

Pons TL, Welschen RAM (2002). Overestimation of respiration rates in commercially available clamp-on leaf chambers. Complications with measurement of net photosynthesis. Plant, Cell and Environment 25: 1367-1372. - doi: 10.1046/ j.1365-3040.2002.00911.x

Poorter H, Remkes C, Lambers H (1990). Carbon and nitrogen economy of 24 wild species differing in relative growth rate. Plant physiology 94 : 621-627. [online] URL: http://www.plantphysiol. org/content/94/2/621.short

Poorter H, Werf A, Atkin OK, Lambers H (1991). Respiratory energy requirements of roots vary with the potential growth rate of a plant species. Physiologia Plantarum 83: 469-475. - doi: 10.11 11/j.1399-3054.1991.tb00122.x

Poorter H, Gifford R, Kriedemann P, Wong SC (1992). A quantitative-analysis of dark respiration and carbon content as factors in the growthresponse of plants to elevated $\mathrm{CO}_{2}$. Australian Journal of Botany 40: 501-513. - doi: 10.1071/ BT9920501

Reddy MM, Vani T, Raghavendra AS (1991). Light-enhanced dark respiration in mesophyll protoplasts from leaves of Pea. Australian Journal of Botany 96: 1368-1371. [online] URL: http://www.ncbi.nlm.nih.gov/pubmed/16668343 Reich PB, Walters MB, Ellsworth DS (1992). Leaf life-span in relation to leaf, plant, and stand characteristics among diverse ecosystems. Ecological Monographs 62: 365-392. - doi: 10.2307/2 937116

Reich PB, Walters MB, Ellsworth DS, Vose JM,
Volin JC, Gresham C, Bowman WD (1998). Relationships of leaf dark respiration to leaf nitrogen, specific leaf area and leaf life-span: a test across biomes and functional groups. Oecologia 114: 471-482. - doi: 10.1007/s004420050471 Rodeghiero M, Niinemets U, Cescatti A (2007). Major diffusion leaks of clamp-on leaf cuvettes still unaccounted: how erroneous are the estimates of Farquhar et al. model parameters? Plant, Cell and Environment 30: 1006-1022. - doi: 10 1111/j.1365-3040.2007.001689.x

Ryan MG (1991). Effects of climate change on plant respiration. Ecological Application 1: 157 167. - doi: $10.2307 / 1941808$

Schimel DS (1995). Terrestrial ecosystems and the carbon cycle. Global Change Biology 1: 7791. - doi: 10.1111/j.1365-2486.1995.tb00008.x

Shapiro JB, Griffin KL, Lewis JD, Tissue DT (2004). Response of Xanthium strumarium leaf respiration in the light to elevated $\mathrm{CO}_{2}$ concentration, nitrogen availability and temperature. New Phytologist 162: 377-386. - doi: 10.1111/j. 1469-8137.2004.01046.x

Sharp RE, Matthews MA, Boyer JS (1984). Kok effect and the quantum yield of photosynthesis: light partially inhibits dark respiration. Plant physiology 75: 95-101. - doi: 10.1104/pp.75.1. 95

Siedow JN, Day DA (2000). Respiration and photorespiration. In: "Biochemistry and molecular biology of plants" (Buchanan B, Gruissem W, Jones R). American Society of Plant Physiologists, Rockville, MD, USA, pp. 676-728.

Tcherkez G, Cornic G, Bligny R, Gout E, Ghashghaie J (2005). In vivo respiratory metabolism of illuminated leaves. Plant Physiology 138: 1596-1606. [online] URL: http://www.ncbi.nlm.nih.gov/pubmed/15980193 Tcherkez G, Bligny R, Gout E, Mahé A, Hodges $\mathrm{M}$, Cornic G (2008). Respiratory metabolism of illuminated leaves depends on $\mathrm{CO}_{2}$ and $\mathrm{O}_{2}$ conditions. Proceedings of the National Academy of Sciences USA 105: 797-802. - doi: 10.1073/pn as.0708947105

Tingey DT, Lee EH, Phillips DL, Rygiewicz PT, Waschmann RS, Johnson MG, Olszyk DM (2007). Elevated $\mathrm{CO}_{2}$ and temperature alter net ecosystem $\mathrm{C}$ exchange in a young Douglas fir mesocosm experiment. Plant Cell and Environment 30: 1400-1410. - doi: 10.1111/j.1365-304 0.2007.01713.x

Tjoelker MG, Oleksyn J, Lee TD, Reich PB (2001). Direct inhibition of leaf dark respiration by elevated $\mathrm{CO}_{2}$ is minor in 12 grassland species. New Phytologist 150: 419-424. - doi: 10.1046/j. 1469-8137.2001.00117.x

Turpin DH, Weger HG (1990). Interactions between photosynthesis, respiration and $\mathrm{N}$ assimilation. In: "Plant physiology, Biochemistry and Molecular Biology" (Dennis DT, Turpin DH eds). Longman Scientific and Technical, Harlow, UK, pp. 422-433.

Villar R, Held AA, Merino J (1994). Comparison of methods to estimate dark respiration in the light in leaves of two woody species. Plant physiology 105: 167-172. [online] URL: http:// www.- 
plantphysiol.org/content/105/1/167.short

Villar R, Held AA, Merino J (1995). Dark leaf respiration in light and darkness of an evergreen and a deciduous plant species. Plant physiology 107: 421-427. [online] URL: http://www.plantphysiol.org/content/107/2/421.short

Vose JM, Ryan MG (2002). Seasonal respiration of foliage, fine roots, and woody tissues in relation to growth, tissue $\mathrm{N}$, and photosynthesis. Global Change Biology 8: 182-193. - doi 10.1046/j.1365-2486.2002.00464.x

Wang XZ, Lewis JD, Tissue DT, Seemann JR, Griffin KL (2001). Effects of elevated atmospheric $\mathrm{CO}_{2}$ concentration on leaf dark respira- tion of Xanthium strumarium in light and in darkness. Proceedings of the National Academy of Sciences USA 98: 2479-2484. - doi: 10.1073/ pnas.051622998

Warren CR, Adams MA (2002). Phosphorus affects growth and partitioning of nitrogen to $\mathrm{Ru}-$ bisco in Pinus pinaster. Tree Physiology 22: 1119. - doi: 10.1093/treephys/22.1.11

Wohlfahrt G, Bahn M, Haslwanter A, Newesely C, Cernusca A (2005). Estimation of daytime ecosystem respiration to determine gross primary production of a mountain meadow. Agricultural and forest meteorology 130: 13-25. - doi: 10.10 16/j.agrformet.2005.02.001
Zaragoza-Castells J, Sánchez-Gómez D, Valladares F, Hurry V, Atkin OK (2007). Does growth irradiance affect temperature dependence and thermal acclimation of leaf respiration? Insights from a Mediterranean tree with long-lived leaves. Plant Cell and Environment 30: 820-833. - doi: 10.1111/j.1365-3040.2007.01672.x

Zou DH, Gao KS, Xia JR (2011). Dark respiration in the light and in darkness of three marine macroalgal species grown under ambient and elevated $\mathrm{CO}_{2}$ concentrations. Acta Oceanologica Sinica 30: 106-112. - doi: 10.1007/s13131-0110096-5 